\title{
c-MYC-Induced Genomic Instability
}

\author{
Alexandra Kuzyk and Sabine Mai \\ Manitoba Institute of Cell Biology, University of Manitoba, CancerCare Manitoba, Winnipeg, Manitoba \\ R3E 0V9, Canada \\ Correspondence: smai@cc.umanitoba.ca
}

MYC dysregulation initiates a dynamic process of genomic instability that is linked to tumor initiation. Early studies using MYC-carrying retroviruses showed that these viruses were potent transforming agents. Cell culture models followed that addressed the role of MYC in transformation. With the advent of MYC transgenic mice, it became obvious that MYC deregulation alone was sufficient to initiate B-cell neoplasia in mice. More than $70 \%$ of all tumors have some form of c-MYC gene dysregulation, which affects gene regulation, microRNA expression profiles, large genomic amplifications, and the overall organization of the nucleus. These changes set the stage for the dynamic genomic rearrangements that are associated with cellular transformation.

\begin{abstract}
Cenomic instability is an enabling feature of Cancer cells (Hanahan and Weinberg 2011). MYC is one of its drivers and will be reviewed in this article from its early days to the present. Special focus will be given to MYC's ability to induce genomic instability and DNA damage at multiple levels, its ability to remodel the architecture of a cell's nucleus, and ultimately, its ability to promote neoplasia.
\end{abstract}

\section{EARLY DAYS OF MYC}

Tumor virology, which paved the way for the discovery of oncogenes, began in 1909 with F. Peyton Rous' isolation of the Rous sarcoma virus (Rous 1910, 1911). His "discovery of tumor-inducing viruses" was rewarded with the Nobel Prize in Physiology or Medicine in 1966. In 1989, the Nobel Prize was awarded to J. Michael Bishop and Harold E. Varmus for their discovery of cellular oncogenes (c-onc). Specifically, they showed that the tumor viruses carried a gene derived from cellular DNA that when captured by the virus became an oncogene or cancer-causing gene (Stehelin et al. 1976).

Early studies of transforming viruses led to the discovery of the MYC oncogene. Avian leukosis virus-induced bursal lymphomas were first reported by Ellerman and Bang (1908). Subsequently, a series of avian retroviruses, including MH2, OK10, MH29, and CMII (Duesberg and Vogt 1979; Bister and Duesberg 1980), were isolated and found to contain MYC sequences (Chiswell et al. 1981; Bunte et al. 1983; Hann et al. 1983; Kan et al. 1983; Thompson et al. 1987). The name MYC originated from "myelocytomatosis," which consists of avian leukosis (hematopoietic neoplasm) and sarcomas. The viral MYC $(v-M Y C)$ transcript encodes a chimeric protein that usually includes

Editors: Chi V. Dang and Robert N. Eisenman

Additional Perspectives on MYC and the Pathway to Cancer available at www.perspectivesinmedicine.org

Copyright (C) 2014 Cold Spring Harbor Laboratory Press; all rights reserved; doi: 10.1101/cshperspect.a014373 Cite this article as Cold Spring Harb Perspect Med 2014;4:a014373 
a portion of the retroviral structural protein encoded by the GAG gene. During this same time period, Hayward et al. (1981), Neel et al. (1981), Cooper (1982), Payne et al. (1982), and Neiman et al. (1985) documented insertional activation of the c-MYC gene by the nononcogene-containing avian leukosis virus, which integrated into and activated the nearby c-MYC gene in bursal lymphomas (Payne et al. 1982).

Balanced chromosomal translocations of MYC in Burkitt's lymphoma documented it as a human oncogene (Manolov and Manolova 1972). Translocations are not only found in Burkitt's lymphoma (Zech et al. 1976), but also in mouse plasmacytoma (Ohno et al. 1979) and rat immunocytoma (Pear et al. 1986). The translocation of the MYC gene juxtaposes it to one of the immunoglobulin (IG) enhancers, which stimulate constitutive MYC expression, driving the neoplastic process (Dalla-Favera et al. 1982; Shen-Ong et al. 1982; Taub et al. 1982).

Transgenic mouse models further documented the causative role of MYC in tumorigenesis, with the first $M Y C$-dependent mouse model of lymphoma created by Adams et al. (1985), allowing deeper insights into MYC-driven neoplasia (discussed in the following section).

\section{TRANSFORMING ACTIVITY OF MYC}

Early studies implicated MYC in cell proliferation (Palmieri et al. 1983), but it was insufficient for cellular transformation unless it cooperated with a second oncogene, RAS, to transform primary embryo fibroblasts (Land et al. 1983, 1986). In contrast, MYC alone was able to transform immortalized Rat1A fibroblasts (Eilers et al. 1989). Transformation was reversible and strictly dependent on MYC levels (Eilers et al. 1989). Similarly, Felsher and Bishop (1999a) observed reversible MYC-dependent tumorigenesis in the lymphoid lineage. Further investigations confirmed these early findings: c-MYC induced mammary tumorigenesis was shown to be reversible when MYC activation was experimentally terminated and KRAS2 was not mutated. However, transformation was irreversible when KRAS2 was mutated (D'Cruz et al. 2001), suggesting that genetic alterations subsequent to $M Y C$ activation contribute to tumor progression. In this regard, it is notable that MYC-induced murine lymphomas regressed with $M Y C$ inactivation unless there were associated complex genomic alterations that allowed tumors to progress and become independent of MYC (Karlsson et al. 2003a,b).

\section{MYC INDUCES GENOMIC INSTABILITY AND DNA DAMAGE}

The studies that investigated MYC's role in the promotion of genomic instability started with the notion that this nuclear oncogene was able to transform cells when deregulated (see previous section). MYC had been shown to enhance viral replication. However, a link to cellular replication, replication stress, and gene amplification was suspected, but not yet proven, when studies into MYC-mediated genomic instability were initiated.

\section{MYC and DHFR}

The first cellular gene investigated in association with MYC and genomic instability was the dihydrofolate reductase (DHFR) gene (Denis et al. 1991). The investigators found DHFR gene amplification and MYC protein elevation after methotrexate (MTX) drug selection. They observed that experimentally overexpressed MYC elevated DHFR copy number within 3 weeks. The investigators found that MYC up-regulated the numbers of MTX-resistant colonies containing 10-fold amplification of the DHFR gene. The enhanced amplification was induced by both MYC and MTX as well as when MYC was induced before the addition of MTX, albeit to a lower level (threefold). Although this work was highly relevant to the question of whether MYC promoted genomic instability of cellular genes, the combination of oncogene deregulation and MTX drug selection complicated the analysis.

Our first studies aimed to dissociate MYC gene deregulation from drug selection and possible clonal evolution that tends to occur in cells grown over several weeks (Lacoste et al. 2010). We focused on mouse, rat, hamster, and human 
MYC and Genomic Instability

cells, in which a single transient conditional expression of c-MYC led to the locus-specific amplification of the DHFR gene (Mai 1994; Mai et al. 1996b). Our studies did not involve drug selection and did not allow the cells to propagate over a 3-week period. Instead, we observed DHFR copy number gains within $72 \mathrm{~h}$ after conditional MYC expression (Fig. 1).

We documented copy number increases of DHFR in the whole cell population by Southern blot analysis and also performed fluorescent in situ hybridization (FISH) to clarify whether there were individual cells or cell subpopulations that showed DHFR gene amplification when c-MYC was transiently overexpressed. Indeed, every cell expressing the conditional MYC gene showed DHFR amplification. Using a mouse mammary tumor virus long terminal repeat (MMTV-LTR)-driven c-MYC cDNA (exons II and III) and a single dexamethasone induction in independent stably transfected Chinese hamster ovary clones, we noted that DHFR gene amplification was a c-MYC-dependent genomic change in all cells examined (Mai 1994). This amplification was transient when c-MYC deregulation was induced only once (Fig. 1) (Mai et al. 1996b). During this process of transient and reversible DHFR gene amplification, other cellular genes that were studied remained single copy (Mai 1994; Mai et al. 1996b).
We next determined whether MYC-mediated DHFR gene amplification was dependent on the cell system used and found DHFR gene amplification in mouse, hamster, rat, and human cells. Different inducible MYC clones (MMTVLTR or MYC-estrogen receptor fusion protein [MYCER- or MYCER]-driven conditional MYC expression) yielded the same results (Mai 1994; Mai et al. 1996b). Cells showing constitutive MYC deregulation (plasmacytoma cell line MOPC265, Colo320HSR, T47D) also displayed DHFR gene amplification and showed additional rearrangements of the locus (Mai et al. 1996b).

Finally, because all these data were derived from cell lines, we investigated MYC-associated DHFR gene amplification in vivo in the pristane-induced mouse plasmacytoma model (Taylor and Mai 1998). Indeed, the DHFR gene was amplified based on Southern blot and FISH analyses, and this amplification occurred in vivo subsequent to MYC deregulation within the first week of pristane-induced plasmacytomagenesis.

In human preinvasive cervical cancer, $D H F R$ was also amplified in association with c-MYC overexpression (Gujion et al. 2007). The higher the level of MYC, the higher the numbers of cells exhibiting DHFR gene amplification (Guijon et al. 2007). A study by Arvanitis and Spandidos
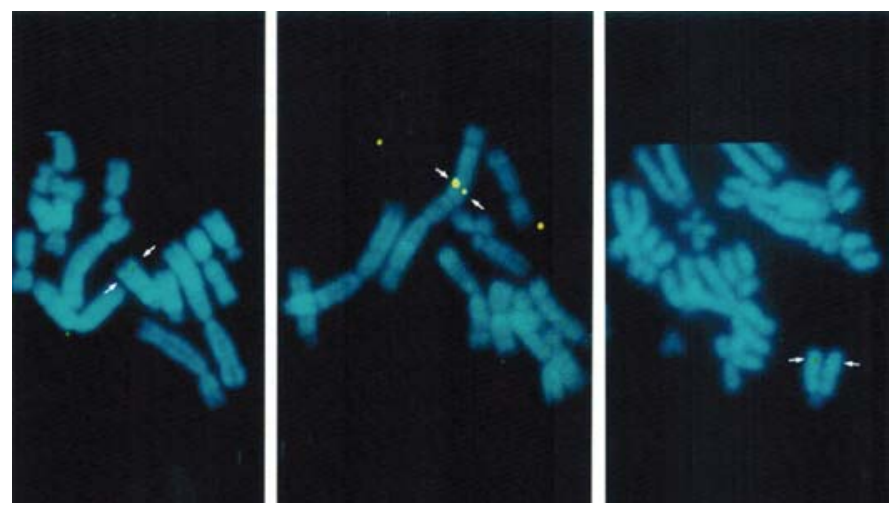

Figure 1. MYC-dependent transient amplification of the DHFR locus. DHFR gene amplification is dependent on MYC overexpression. Partial metaphases showing a transient DHFR gene copy number increase before (left), during (middle), and after (right) a single conditional deregulation of MYC expression. DHFR is shown in green, the chromosomes in blue. (From Mai et al. 1996b; quantitative measurements of these signals have been reprinted, with permission.) 
(2008) next described the deregulation of the $\mathrm{G}_{1} / \mathrm{S}$ transition in intraepithelial lesions and cancer of the cervix and found, among other alterations, MYC and DHFR elevation. Scionti et al. (2008) validated MYC levels and MTX resistance at diagnosis in osteosarcoma and found a direct correlation of MYC levels with MTX resistance. Down-regulation of MYC made the cells more sensitive to MTX. Studies in prostate cancer, prostate cancer cell lines, and metastasis-derived cell lines described a gain in $5 \mathrm{q}$ (El Gedaily et al. 2001; Lensch et al. 2002).

MYC-driven DHFR amplification occurred both intrachromosomally and extrachromosomally; increased DHFR copy numbers were seen within the chromosome with and without rearrangement of the locus and on extrachromosomal elements (Benner et al. 1991; Windle et al. 1991; Mai 1994; Mai et al. 1996b). Both genetic changes lead to additional copy numbers, but point to complex molecular remodeling by breakage, repair, and aberrant replication (see below).

\section{MYC and Other Genes in Genomic Instability}

c-MYC deregulation does not just affect DHFR gene copy numbers. Work over the years has illustrated a number of genes that are amplified as a result of c-MYC overexpression. These amplifications were all found within $72 \mathrm{~h}$ and as a result of a single experimentally induced deregulation of MYC. Chromosomal and extrachromosomal increases in their gene copy numbers were shown by Southern blotting, FISH, and by assessment of isolated extrachromosomal elements (EEs; see also MYC and Extrachromosomal Elements). The affected genes include ribonucleotide reductase $R 2$ ( $R 2$ ) (Kuschak et al. 1999), the carbamyl-P synthetase, aspartate transcarbamylase, dihydro-orotase (CAD) enzyme-encoding gene (Miltenberger et al. 1995; Fukasawa et al. 1997; Chernova et al. 1998; Eberhardy and Farnham 2001), ornithine decarboxylase (George et al. 1996; Rounbehler et al. 2009), cyclin B1, and cyclin D2 (Mai et al. 1999, 2005). The amplification of genes involved in DNA synthesis and cell-cycle progression will provide a proliferative advantage to cells that harbor it (Kuschak et al. 2002). Not only will cells carrying such amplifications experience a growth advantage, but they will also be resistant to some of the cytotoxic drugs such as MTX (Denis et al. 1991) or even radiation (LückeHuhle et al. 1997). It is of note that permissivity to DHFR gene amplification correlates with metastatic potential (Lücke-Huhle 1994).

Certainly, this list only contains a few targets that were examined in this context, and there are many more as additional studies have shown. Rockwood et al. (2002) found that MYC deregulation was associated with illegitimate recombinations and long-range chromosomal rearrangements, but not point mutations. Illegitimate recombinations led to translocations, deletions, and inversions. DNA sequencing and spectral karyotyping indicated that many different chromosomal regions and breakpoints were involved (Rockwood et al. 2002). We now appreciate that c-MYC alters the stability of multiple genes and genomic sites, affecting noncoding RNAs and microRNAs (Huppi et al. 2008, 2011). Genome-wide approaches have helped map loci affected by MYC-driven instability in vivo. In bursal lymphomas, Neiman et al. (2006, 2008) showed that MYC deregulation was associated with tumor-specific palindrome formation that include inverted repeats and MYC binding sites. A consistently included palindrome was that of $\mathrm{bic} / \mathrm{miR}-155$ that was associated with MYC-dependent bursal tumorigenesis and absent from control cells.

The list of genomic sites affected is large, with more than $11 \%$ of all cellular loci being candidates (Fernandez et al. 2003; Orian et al. 2003; Hulf et al. 2005). MYC/MAX heterodimers are estimated to occupy more than $15 \%$ of all gene promoters tested in Burkitt's lymphoma (Li et al. 2003), and more than $45 \%$ of all replication origins in human cells carrying MYC-binding E-box motifs (Swarnalatha et al. 2012). Candidate genes fall into diverse functional pathways such as cell-cycle-regulating genes, cell metabolism-associated genes, angiogenesis, cell adhesion, apoptosis, and metastasis (Grandori et al. 2000; Casillas et al. 2003; O'Connell et al. 2003; Meyer and Penn 2008; Dang 2012). Data by Levens' and Young's 
groups indicate that MYC is a universal amplifier of gene expression in normal and tumor cells (Lin et al. 2012; Nie et al. 2012). Their data argue that MYC is not an on-off regulator of specific gene activity. Instead, MYC appears to regulate all active genes with the exception of immediate early genes in normal cells (Nie et al. 2012) and amplifies the expression of active genes in tumor cells (Lin et al. 2012; see also Levens 2013; Rahl and Young 2014). Distinct from this mechanism of enhanced gene expression and during the onset and propagation of genomic instability, MYC affects the genome through replication-driven, DNA damage- and stress-induced pathways. Moreover, MYC affects genome stability through the remodeling of nuclear architecture. These topics will be discussed in subsequent sections.

\section{MYC and Extrachromosomal Elements}

EEs are small circular DNA motifs that are not part of chromosomes. They are found in all organisms and as such are not associated with malignancy. EEs of normal cells carry mostly repetitive DNA motifs (Gaubatz 1990). They also occur as part of normal physiological processes, such as VDJ and T-cell receptor recombination (for review, see Kuttler and Mai 2007). EEs were noted again in recent work (Richards 2012; Shibata et al. 2012).

Tumor cells carry different types of EEs, the physiological type that is found in normal cells, but also larger EEs that contain genes. These are called episomes and double minutes, respectively, and are able to replicate; the latter will be distributed to daughter cells after cell division, albeit in unequal numbers.

c-MYC-induced EEs may be called episomes because they possess the ability to replicate (Smith et al. 2003). They carry MYC targets of locus-specific genomic instability and are transcriptionally competent or active and, therefore, functional genetic units (Smith et al. 2003). As expected from extrachromosomal genes that are able to be replicated and transcribed, the EEs carry histones, and thus behave as minichromosomes (Smith et al. 2003; for review, see Kuttler and Mai 2007). Importantly, EEs may be the sole drivers of the neoplastic cell as seen in the extrachromosomal translocation of $M Y C / I G$ and MYC overexpression from these EEs in an otherwise chromosomal translocation-free mouse plasmacytoma (Wiener et al. 1999). Another example of extrachromosomal juxtaposition of genes is the NUP214/ABL1 fusion in some cases of T-cell acute lymphoblastic leukemia that results in c- $A B L$ deregulation (Graux et al. 2004). Whether MYC is involved in the latter fusion event is not known.

\section{Karyotypic Instability}

MYC not only alters single chromosomal loci, but promotes an overall induction of chromosomal instability, also termed karyotypic instability. Induced c-MYC deregulation results in a variety of chromosomal changes; among these are the formation of extrachromosomal elements (for review, see Kuttler and Mai 2007), centromere and telomere fusions (Mai et al. 1996a), chromosome and chromatid breaks, ring chromosomes, translocations, deletions and inversions, aneuploidy, and the formation of Robertsonian chromosomes (Fig. 2) (Mai et al. 1996a; Felsher and Bishop 1999b; Rockwood et al. 2002; Guffei et al. 2007; Gonçalves Dos Santos Silva et al. 2008; Silva et al. 2010; Chen et al. 2011). Recent reviews have addressed this role of MYC in instability (Dang et al. 2005; Prochownik and Li 2007; Prochownik 2008). Also, genome-wide approaches have highlighted MYC's overall potential to impact the genomic stability of the cell (Neiman et al. 2006, 2008). However, once instability is present, MYC does not always promote additional genomic instability (Gao et al. 2007).

\section{p53, MYC, and Genomic Instability}

MYC-dependent genomic instability is enhanced when $p 53$ is absent. The mouse plasmacytoma is an excellent model to address MYC-dependent instability in a p53-deficient background. Plasmacytomas (PCTs) are B-lineage tumors. In susceptible mice, PCTs are traditionally induced by mineral oils and plastic implants (Potter and Wiener 1992). These agents 

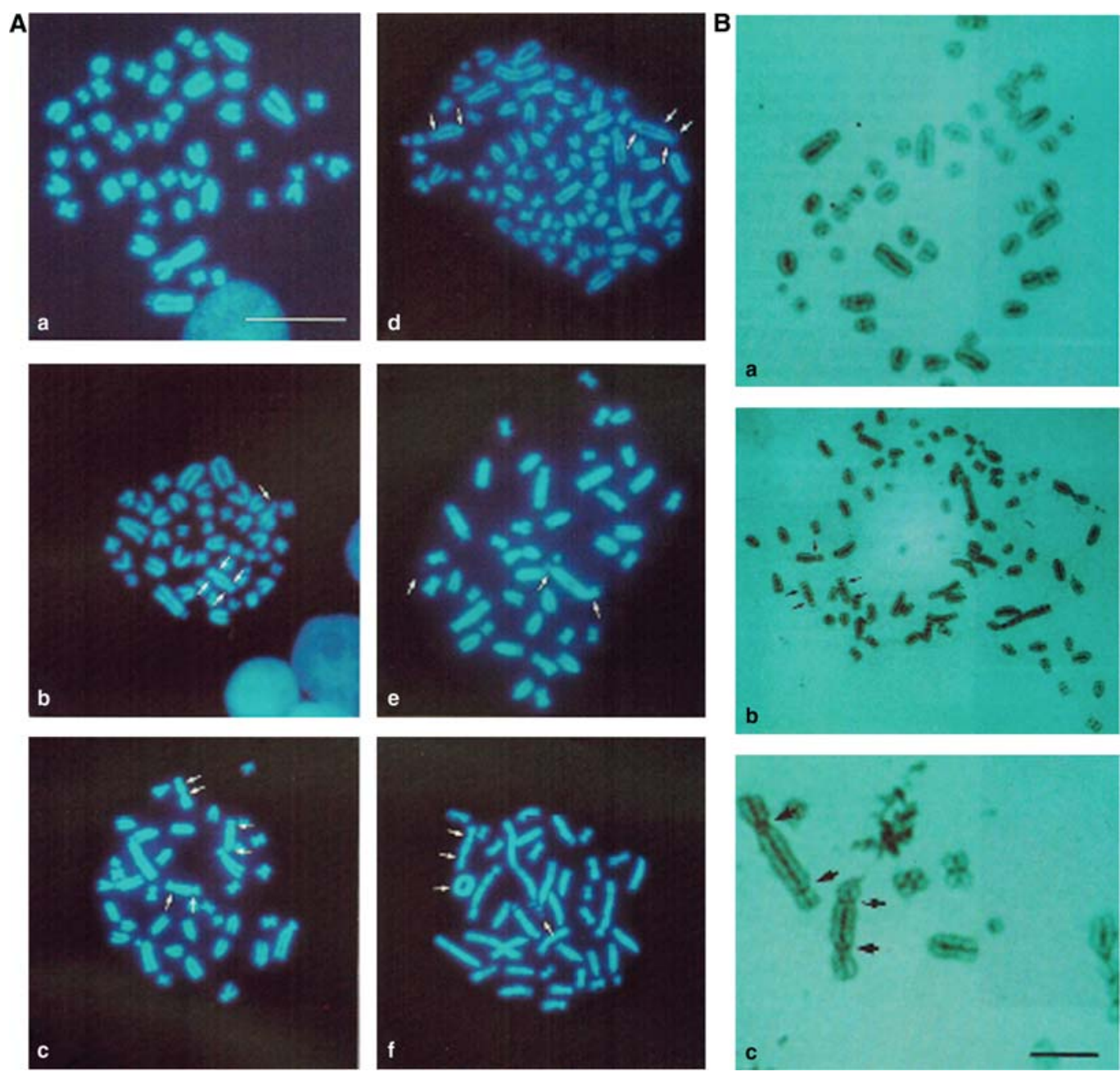

Figure 2. MYC-dependent karyotypic instability. (A) Shown are six individual and representative metaphase plates of Rat1A-MycER cells shown in the absence $(a)$ and presence of transient MYC deregulation $(b-f)$. Arrows highlight typical chromosomal aberrations, including chromatid breaks $(b)$, centromere-telomere fusions $(b-f)$ and the presence of ring chromosomes $(f)$. Extrachromosomal elements are noted as well $(f)$. (B) Centromeric staining reveals centromere-telomere fusions. Control Rat1A-MycER cells are shown in $a$. Centromere-telomere fusions are highlighted by arrows in $b$ and $c$. Scale bars, $50 \mu \mathrm{m}(A) ; 10 \mu \mathrm{m}(B)$ (From Mai et al. 1996a; reprinted, with permission.)

cause chronic inflammation and allow the neoplastic development of PCTs that are all characterized by deregulated expression of MYC, which is caused by the chromosomal translocation of MYC to one of the immunoglobulin loci (Potter and Wiener 1992; Wiener et al. 1999).

Mouse strains susceptible to PCT development are BALB/c and NZB mice (Potter and Wiener 1992). Other mouse strains, such as
C57BL6 and 129Sv, are resistant to the classical induction schemes (Potter and Wiener 1992). To examine the impact of $p 53$ loss on PCT development, $p 53^{-/-}$mice (Donehower et al. 1992) with a PCT-resistant genetic background of 75\% C57BL6 and 25\% 129Sv (Taconic Farms, Germantown, NY) were crossed with BALB/c congenics and examined in the presence or absence of one or two p53 alleles (Mai and Wiener 
2002). PCT development was then induced in these mice using pristane. The F1 $\left(p 53^{+/-}\right)$ mouse generation developed PCTs at a frequency of $11.5 \%$ (Mai and Wiener 2002). The number of pristane-induced PCTs increased to $42 \%$ in the $\mathrm{N} 3 p 53^{-/-}$mice of this mixed genetic background, but no PCTs developed in the respective $\mathrm{N} 3 p 53^{+/+}$controls. The mean latency in the $\mathrm{N} 3 p 53^{-/-}$mice was 146 days (range $97-$ 316 ). The incidence was $37.5 \%$ with a mean latency of 189 days (range 126-266) in the $p 53^{+/+}$BALB/c controls (Mai and Wiener 2002). These data confirmed that the presence of $p 53^{+/+}$in the resistant background (C57BL6 and Sv129) inhibits PCT genesis, even in N3 mice. However, the absence of $p 53$ overcomes the resistance to PCT development.

The next important finding of this study was the change in frequencies of common translocations observed in PCTs. The c-MYC/IgH translocation is the most common $M Y C$-activating translocation in mouse PCTs (Potter and Wiener 1992). The ratio of the typical c$M Y C / I g H$ translocation to the less frequent variant translocations, involving $M Y G / I g \kappa$ or $M Y C / I g \lambda$, is 9 to 1 . The $M Y C$-activating translocations in $p 53$-deficient mice were both the typical and variant types with a $41.6 \%$ frequency for each (a 1:1 ratio). Translocation-negative tumors were also found in $16.6 \%$ of the cases. Extrachromosomal MYC/Ig translocation elements were frequently observed in these latter cases (Wiener et al. 1999; Mai and Wiener 2002). Thus the absence of $p 53$ affected the resistance, latency, and incidence of PCT development and impacted on the most common translocation frequencies.

$M Y C$ and $p 53$ are interconnected (Ragimov et al. 1993), such that deregulated MYC in p53deficient young mice induced genomic instability (Fukasawa et al. 1997). Not only was there a large number of cells expressing elevated levels of c-MYC, but the MYC target genes DHFR and $C A D$ were also amplified both intrachromosomally and extrachromosomally. In addition, centrosome duplication was aberrant in vivo and aneuploidy was frequent. Remarkably, bone marrow, spleen, thymus, fibroblasts, and fetal liver cells displayed aneuploidy in the ab- sence of p53 (Fukasawa 1996, 1997, 2007). The aneuploidy ranged from $5 \%$ in fetal liver cells to $34.8 \%$ in fibroblasts with $25.6 \%$ in thymocytes, $10 \%$ in bone marrow cells, and $20 \%$ in spleen cells from young (4- to 6-week-old) mice. MYC, $C A D$, and DHFR were coamplified in the same cells that showed MYC deregulation. Apoptosis was frequent in all organs examined, but less frequent in thymus.

\section{c-MYC Mutants and Genomic Instability}

Genomic instability of MYC can be separated genetically from its transforming activity. MYC mutants in MYC box II are defective in transformation of immortalized Rat1A cells (Eilers et al. 1989) and unable to induce tumors in vivo (Adams et al. 1985). Induction of instability by MYC mutant proteins was examined in $\mathrm{Ba} / \mathrm{F} 3$ cells that conditionally expressed MycERdriven MYC box II mutants (B16 and $\Delta 106$ ) (Fest et al. 2002, 2005). These MYC mutants were able to induce, within $48 \mathrm{~h}$, genomic instability that included structural and numerical aberrations, gene amplification, the formation of EEs, chromosomal breakage, increased aneuploidy, and polyploidization. However, telomeric aggregation was not induced and required a functional MYC box II (Caporali et al. 2007). In addition, instability associated with MYC box II deletion mutants was insufficient to promote tumorigenesis in mice (Fest et al. 2005). Thus, instability alone does not always enable neoplasia; it depends on the type and extent of instability. Too much instability prevents tumor development, probably by triggering apoptosis. This concept was clearly established by additional studies that focused on the level of tumor-promotion and tumor inhibition by aneuploidy in vivo (Weaver et al. 2006; Zasadil et al. 2013).

\section{MYC and Replication versus Illegitimate Replication}

Early data on MYC overexpression-mediated stimulation of replication of Simian Virus 40 (Classon et al. 1987, 1990; Henriksson et al. 1988) suggested that the oncoprotein played a role in DNA replication. This notion was heavily 
debated over the years; however, it turned out to be correct as postulated early on (Classon et al. 1987). Dominguez-Sola et al. (2007) showed that MYC was involved in normal DNA replication, specifically during the initiation of replication and during replication stress.

What happens when c-MYC is deregulated? How does it affect replication initiation? Studies by Li and Dang (1999), Gandarillas et al. (2000), and Pierce et al. (2004) gave the next insights into these questions. They showed that MYC deregulation could lead to DNA endoreduplication and polyploidy. In Li and Dang's work, MYC drove endoreduplication after a mitotic block. In Gandarillas' study, MYC upregulation was followed by endoreduplication in keratinocytes before their terminal differentiation. Pierce et al. (2004) showed that Myc was required for larval endoreduplication in the absence of cell division (see also Gallant 2013).

Work by our group next showed that MYC was able to promote illegitimate DNA replication resulting in more than one replication firing per origin per cell cycle (Kuschak et al. 2002). Interestingly, in diploid synchronized PreB mouse lymphocytes, after a single pulse of conditional MYC deregulation, the $R 2$ gene was replicated more than once in early $S$ phase (Kuschak et al. 2002). Using two-dimensional gel electrophoresis of DNA harvested before and throughout $S$ phase as well as mitotic chromosomes from BrdU-pulse labeled cells, we found that MYC was able to deregulate the normal "once per cycle" replication initiation of $R 2$ that was observed in the control cells and for the control gene cyclin C. MYC forced three to four replication initiation forks and replication proceeded on both alleles, not just in a monoallelic fashion as seen in control cells (Kuschak et al. 2002). MYC acted as an illegitimate replication-licensing factor. We concluded at this time that the types of $R 2$ amplification observed as a result of MYC deregulation were in agreement with replication-driven instability (Kuschak et al. 1999, 2002). Other genes that undergo MYC-dependent gene amplification, such as Cyclin D2 and DHFR, also follow a replication-dependent mechanism (SF Louis and S Mai, unpubl.).
Recently, Swarnalatha et al. (2012) studied the epigenetic control of E-box binding and MYC-dependent replication initiation of lamin B2. The investigators documented cell-cycledependent epigenetic changes at the lamin B2 E box and MYC occupancy as the cells entered $S$ phase. MYC binding was followed by the recruitment of the minichromosome maintenance proteins and origin licensing. The investigators concluded that cross talk between histone modifications and MYC E-box binding is required for origin firing.

Barlow et al. (2013) recently identified MYC-induced DNA damage at early replication fragile and common fragile sites. Such replication stress-induced damage can result in chromosomal rearrangements. Hot spots of early replication fragile sites and common translocations frequently overlap in tumors (Barlow et al. 2013). This damage affects early fragile and common fragile sites in the whole genome. Thus, MYC affects more than single loci and effectively modifies the genome. The work on transcription and MYC by the groups of Levens and Young (Lin et al. 2012; Nie et al. 2012) promotes this concept on the transcriptional level. Dominguez-Sola et al. (2007) describe the global role for MYC in replication. Our data suggest that genes whose origins fire early in S phase are susceptible to MYC-dependent amplification (Kuschak et al. 2002; SF Louis and S Mai, unpubl.). For genomic instability to promote transformation and tumor progression, amplified and rearranged loci must provide a selective survival advantage and overcome the repressive effects of their microenvironment.

\section{MYC and DNA Damage}

MYC is not just a potent inducer of genomic changes as outlined. It has the ability to mediate DNA damage, as first described by Vafa et al. (2002). Vafa et al. (2002) provided evidence for DNA breaks caused by the reactive oxygen species (ROS) produced from brief MYC expression in normal human fibroblasts; this DNA damage occurred in the absence of apoptosis indicating that MYC overexpression may compromise the DNA damage response. The investigators sug- 
gested that the increase in ROS may be the result of a biochemical imbalance caused by the sudden increase in gene products via MYC's transcriptional activation (Vafa et al. 2002).

The increased expression of MYC causes an accumulation of ROS, which generate DNA breaks (Khanna and Jackson 2001). ROS increase in both normal and serum-depleted cultures of NIH3T3 and Saos-2 MYC-overexpressing cell lines was described by Tanaka et al. (2002). More specifically, MYC induces a mitochondrial gene, TFAM, which encodes a protein essential for mitochondrial function and biogenesis, and may lead to increased ROS (Dang et al. 2005). PRDX3, which plays an important role in protection of ROS produced in hypoxic conditions, is also a target gene of MYC in Ratla cells (Wonsey et al. 2002). Additional genes involved in ROS and regulated by MYC have been reviewed by Prochownik (2008). In in vivo studies, using a transgenic mouse model of hepatocarcinogenesis, overexpression of TGF- $\alpha$ and c-MYC led to chronic oxidative stress followed by impaired DNA damage response, genomic instability, and, ultimately, tumor progression (Hironaka et al. 2003).

However, a more recent study showed that MYC can also cause DNA double-stranded breaks (DSBs) independent of ROS production and proposed that DNA breaks may occur by different mechanisms based on the growth conditions (Ray et al. 2006). Using a MYCER-inducible system and immunofluorescence to stain for markers of single-stranded breaks (APE-1) and DSBs $(\gamma-\mathrm{H} 2 \mathrm{AX})$, the investigators found that on $M Y C$ induction, ROS-independent DSBs were observed in normal human foreskin fibroblasts cultured in normal $(10 \%)$ serum in vitro and murine lymphocytes in vivo. In contrast, ROSassociated single-stranded breaks were observed for normal foreskin fibroblasts cultured in low $(0.05 \%)$ serum and ambient oxygen saturation (Ray et al. 2006).

\section{MYC and Replication Stress}

MYC overexpression up-regulates transcription of numerous genes that consequently increase replication origin firing, a mechanism that Campaner and Amati (2012) propose leads to an increase in the DNA damage accumulated during S phase. MYC can also override cell-cycle checkpoints that would otherwise dictate cellcycle arrest. A brief increase in MYC activity accelerated Rat $1 \mathrm{~A}$ cells through the $\mathrm{G}_{1} / \mathrm{S}$ transition and allowed these cells to continue to G2 (Felsher and Bishop 1999b). This occurred even in the presence of $N$-(phosphonoacetyl)L-aspartate, which normally arrests cells in $S$ phase. MYC overexpression was found to uncouple DNA replication from mitosis as colcemid-arrested human and rodent cells continued to replicate their DNA resulting in apoptosis or polyploidy depending on p53 status ( $\mathrm{Li}$ and Dang 1999). By comparing human foreskin fibroblasts to MYC-deficient rat cells, Robinson et al. (2009) observed that the deficient cells had a prolonged S phase, whereas the overexpression of MYC accelerated S phase; they also proposed a novel role for Werner DNA helicase (WRN) in S-phase acceleration (Robinson et al. 2009).

A third mechanism of replication stress involves disruptions in the repair of DSBs. The idea that MYC interferes with gene products that mediate DNA break repair was proposed by Karlsson et al. after their observation of severe magnitude increases in chromosome breaks in normal human foreskin fibroblasts through DSB assays (Karlsson et al. 2003). It was later determined by tandem affinity purification with mass spectral multidimensional protein identification technology proteomics that MYC regulates nonhomologous end-joining (NHEJ) factors (Koch et al. 2007), and a recent investigation concluded that MYC directly suppresses the NHEJ pathway causing inhibition of DSB repair and $\mathrm{V}(\mathrm{D}) \mathrm{J}$ recombination through inhibitory MYC box II binding with $\mathrm{Ku} 70$ in vitro and in vivo ( $\mathrm{Li}$ et al. 2012). It has also been reported that MYC inhibits homologous recombination through regulation of RAD51 in various cancer cell lines (Luoto et al. 2010). Recently, Campaner and Amati (2012) have proposed that replication stress may result from metabolic starvation of nucleotides, or from a clash of RNA polymerase-mediated transcription and DNA replication machinery caus- 
ing replication fork collapse, mechanisms that both need experimental validation.

\section{MYC AND DNA DAMAGE AND REPAIR}

Although DNA damage can limit cellular lifespan, cells with overexpression of MYC also have an impaired DNA damage response and can activate DNA damage response (DDR) mechanisms that instead lead to genomic instability and tumor progression. MYC-induced DDR can act in both tumor-suppressive and tumorpromoting manners. The ataxia telangiectasia mutated (ATM) pathway is activated by DSBs and usually leads to apoptosis and halts malignant transformation. In contrast, the ataxia telangiectasia and Rad3-related (ATR) pathway allows for cellular proliferation and results in tumor progression. These competing pathways are reviewed by Campaner and Amati (2012).

Following DNA DSBs, the ATM protein kinase activates substrates involved in DDR, which ultimately leads to the activation of p53 and tumor suppression through apoptosis. Many studies have linked the ATM protein kinase to MYC; $A T M^{-/-}$mouse thymic lymphomas show extra copies of the chromosomal region harboring MYC (Liyanage et al. 2000), and B-cell tumors induced in $E \mu-M Y C$ transgenic mice have a reduced MYC-induced DDR and accelerated tumorigenesis with ATM loss (Adams et al. 1985). MYC overexpression was shown to induce the DDR through up-regulation of ATM. MYC overexpression was shown to activate ATM and p53 through phosphorylation and induce the DNA damage response as evidenced by the creation of $\gamma$-H2AX and phospho-SMC1 foci in vivo in a transgenic mouse model overexpressing MYC in squamous epithelial tissues (Pusapati et al. 2006). Furthermore, E $\mu$-MYC; $A T M^{-/-}$mice developed pre-B and B-cell lympho-leukemias that displayed shorter latency compared with $E \mu-M Y C ; A T M^{+/+}$and $A T M^{-/-}$mice that died of thymic lymphomas (Maclean et al. 2007). Also, in $E \mu-M Y C$-induced mouse lymphomas, the loss of WIP1, which negatively regulates ATM, drastically delayed tumor onset (Shreeram et al. 2006). TIP60, which plays a role in the ATM DDR by inducing acetylation of ATM in response to DNA damage (Sun et al. 2005), was proposed to be a haplo-insufficient tumor suppressor for pre- or early-stage lymphomas. E $\mu$-MYC/Tip60 ${ }^{+/-}$transgenic mice had accelerated tumors and an impaired DDR evidenced by decreased ATM phosphorylation compared with E $\mu$-MYC/Tip60 $0^{+/+}$mice (Gorrini et al. 2007). Tumors may evolve to develop mutations in this pathway to avoid tumor suppression; therefore, treatments that require a functional DDR will not be effective, but rather synthetic lethal approaches may be more successful (Bryant et al. 2005). For example, lymphoma cells from $\lambda-M y c$ transgenic mice acquired inactivation of CHK2, which had a synergistic lethal interaction with the DNA repair inhibitor Poly (ADP-ribose) polymerase (Höglund et al. 2011b).

$M Y C$ regulates many DNA DSB repair genes such as APEX, BRCA1, BRCA2, DNA-PKcs, Ku70, MSH2, NSB1, Rad50, Rad51, and Rad54L (Menssen and Hermeking 2002; Chiang et al. 2003; Fernandez et al. 2003; Li et al. 2003; Luoto et al. 2010). MYC also regulates mismatch repair genes. For example, MYC down-regulation correlated with decreased levels of $\mathrm{MSH} 2$ and MLH1 in a gamma radiation-treated melanoma cell line (Bucci et al. 2005). It was also observed in hypoxic conditions in multiple tumor cell lines that the promoters of $\mathrm{MSH} 2$ and $\mathrm{MLH1}$ changed from being occupied by MYC/MAX to $\mathrm{MAX} / \mathrm{MAD} 1$ and $\mathrm{MAX} / \mathrm{MNT}$ complexes (Bindra and Glazer 2007; see Hurlin 2013 and Conacci-Sorrell et al. 2014 for a description of the MXD/MNT proteins).

Overexpression of MYC also induces tumorpromoting DDR mechanisms. First of all, MYC was shown to up-regulate the WRN helicase, responsible for resolving unfavorable structures formed during $\mathrm{S}$ phase (Sidorova et al. 2008), through direct binding of its promoter by MYC/MAX complexes in four MYC-overexpressing cell lines (Grandori et al. 2003). In the absence of WRN, fibroblasts, non-small cell lung cancer cell lines, and $\mathrm{E} \mu-\mathrm{MYC}$ transgenic mice with MYC activation showed an increase in the DDR and a delay in tumor growth (Robinson et al. 2009; Moser et al. 2012). Second, MYC plays a role in increasing nucleotide 
synthesis to avoid nucleotide starvation from the increase in gene transcription. Liu et al. (2008) show this in multiple systems; chromatin immunoprecipitation with paired-end ditag sequencing analysis on a immortalized B-lymphocyte cell line, followed by qPCR on the products, showed that many genes involved in de novo nucleotide synthesis had E boxes in their promoters or first introns, were up-regulated on MYC induction, and therefore are candidates for being directly regulated by MYC. In MYC transgenic mouse livers, most of these target genes had increased expression on MYC induction. Also, when MYC was inhibited through lentivirus-based shRNAs in human metastatic melanoma cell lines, the genes encoding enzymes important for dNTP metabolism were repressed and the amount of dNTPs were reduced (Mannava et al. 2008). Last, Myc controls the ATR DNA repair pathway that is activated in response to specific single-stranded DNA produced during replication stress (Schoppy et al. 2012). Components of this pathway are also potential therapeutic targets as their inhibition in cells with Myc overexpression can result in increased DNA damage and trigger an apoptotic response. For example, inhibiting CHK1/CHK2 (proteins activated by ATR that in turn activate cell-cycle checkpoints, replication fork progression, and anti-apoptotic activity) (Cimprich and Cortez 2008; López-Contreras and Fernandez-Capetillo 2010) increases DNA damage, the DDR, apoptosis, and, ultimately, cell death in human cancer cell lines and in the $E \mu-M Y C$ mouse model of lymphoma (Cole et al. 2011; Ferrao et al. 2011; Höglund et al. 2011a,b). In a mouse model of Atr-Seckel syndrome, Atr ${ }^{\mathrm{S} / \mathrm{s}}$ $E \mu-M Y C^{+}$mice (hypomorphic for Atr) did not develop lymphomas, but $E \mu-M Y C$ aggravates Seckel syndrome symptoms (microcephaly, micrognathia, pancytopenia, and kyphosis) leading to their decreased survival time compared with $\mathrm{Atr}^{+/+} E \mu-M Y C^{+}$mice (Murga et al. 2011).

In summary, the opposing tumor promoting and suppressive pathways enabled by MYC overexpression both provide potential opportunities for anticancer therapies. However, what remains to be resolved is how these pathways interact in individual tumors and whether their competitive nature permits them to work in parallel, or if one pathway prevails. Only when this is clarified can the true value of therapeutic intervention be determined.

\section{MYC and Nuclear Organization}

c-MYC-induced genomic instability acts on the interphase nucleus, which it remodels such that dynamic processes of instability are initiated (for review, see Mai 2010; Gadji et al. 2011). Three-dimensional (3D) imaging has allowed us to investigate the impact of c-MYC on the organization of the nucleus (Chuang et al. 2004; Louis et al. 2005; Mai and Garini 2005, 2006; Vermolen et al. 2005). A single induction of deregulated c-MYC led to multiple changes in nuclear organization that altered the position and function of telomeres, selectively induced chromosome movement and overlap (Louis et al. 2005; Mai and Garini 2005), and induced Robertsonian fusions (Fig. 3A) (Guffei et al. 2007; Mai and Garini 2005). MYC deregulation for as short as $2-12 \mathrm{~h}$ resulted in nuclear remodeling of the 3D organization and position of telomeres and chromosomes (Louis et al. 2005; Mai and Garini 2005). Telomere remodeling led to the formation of telomeric aggregates and fusions that initiated breakage-bridge fusion cycles (Fig. 3B) (Louis et al. 2005; Mai and Garini 2005). Chromosome remodeling juxtaposed chromosomes that were usually found in distinct chromosomal territories and enabled chromosomal rearrangements. The latter appeared as a combination of telomere dysfunction and chromosomal movements (Louis et al. 2005; Mai and Garini 2005). These data sharpened our view on MYC-driven genomic instability and allowed us to understand that MYC affects nuclear organization and drives dynamic remodeling of chromosomes, genes, and their structural order. This is particularly relevant as gene activation, function, and nuclear space are functionally linked (Solovei et al. 2009). Nuclear remodeling occurs during early malignancy and sets the stage for neoplastic transformation (Mai and Garini 2005, 2006; Gadji et al. 2011, 2012). 
A. Kuzyk and S. Mai

\section{CONCLUDING REMARKS}

Because of MYC's ability to induce cellular transformation through multiple pathways, the term "mutator phenotype" was coined for this oncoprotein (Beckman and Loeb 2005; reviewed in Prochownik 2008). MYC is deregulated in more than $70 \%$ of all cancers (Nesbit et al. 1999), and many of them are oncogene-addicted (Weinstein 2002); that is, they can only thrive and maintain their malignant phenotype when MYC protein deregulation persists (Felsher and Bishop 1999a; Jain et al. 2002; Gabay et al. 2014). Once new mutations are introduced,
MYC deregulation seems to be no longer required (D'Cruz et al. 2001) suggesting that additional genetic changes will then replace MYC and preserve the tumorigenic phenotype.

MYC overcomes replicative, oncogene-, and stress-induced senescence. By activating or repressing the genes involved in cellular proliferation, tumor suppression, DNA repair, apoptosis, angiogenesis, and invasion, although inducing a wide range of DNA damage and genomic instability, MYC acts as a master regulator of tumor development. In addition, it remodels the nuclear architecture of the cells in which its expression is deregulated and therefore affects the
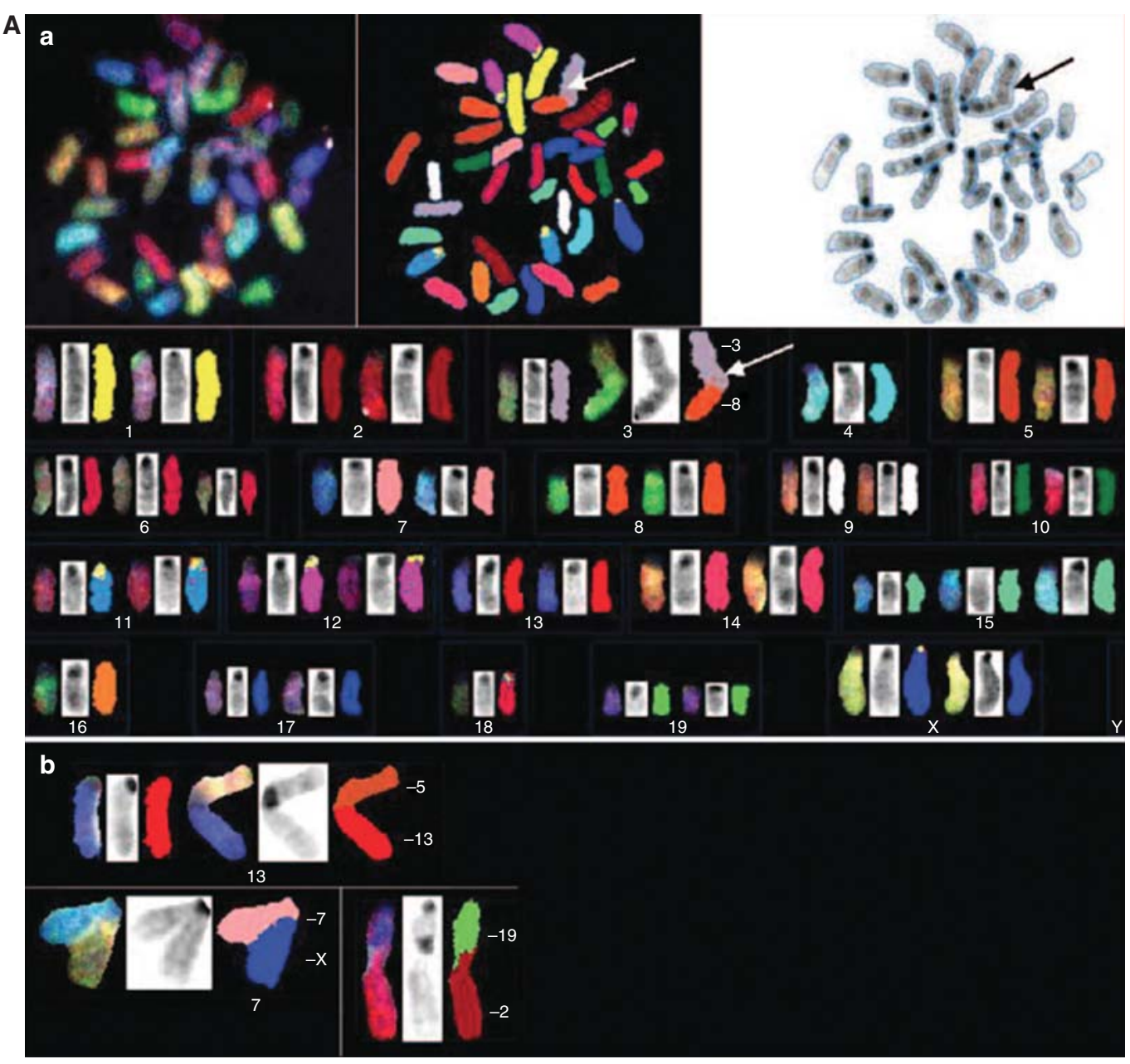

Figure 3. MYC-dependent chromosomal rearrangements subsequent to nuclear chromosome and telomere remodeling. (Legend continues on following page.) 
MYC and Genomic Instability

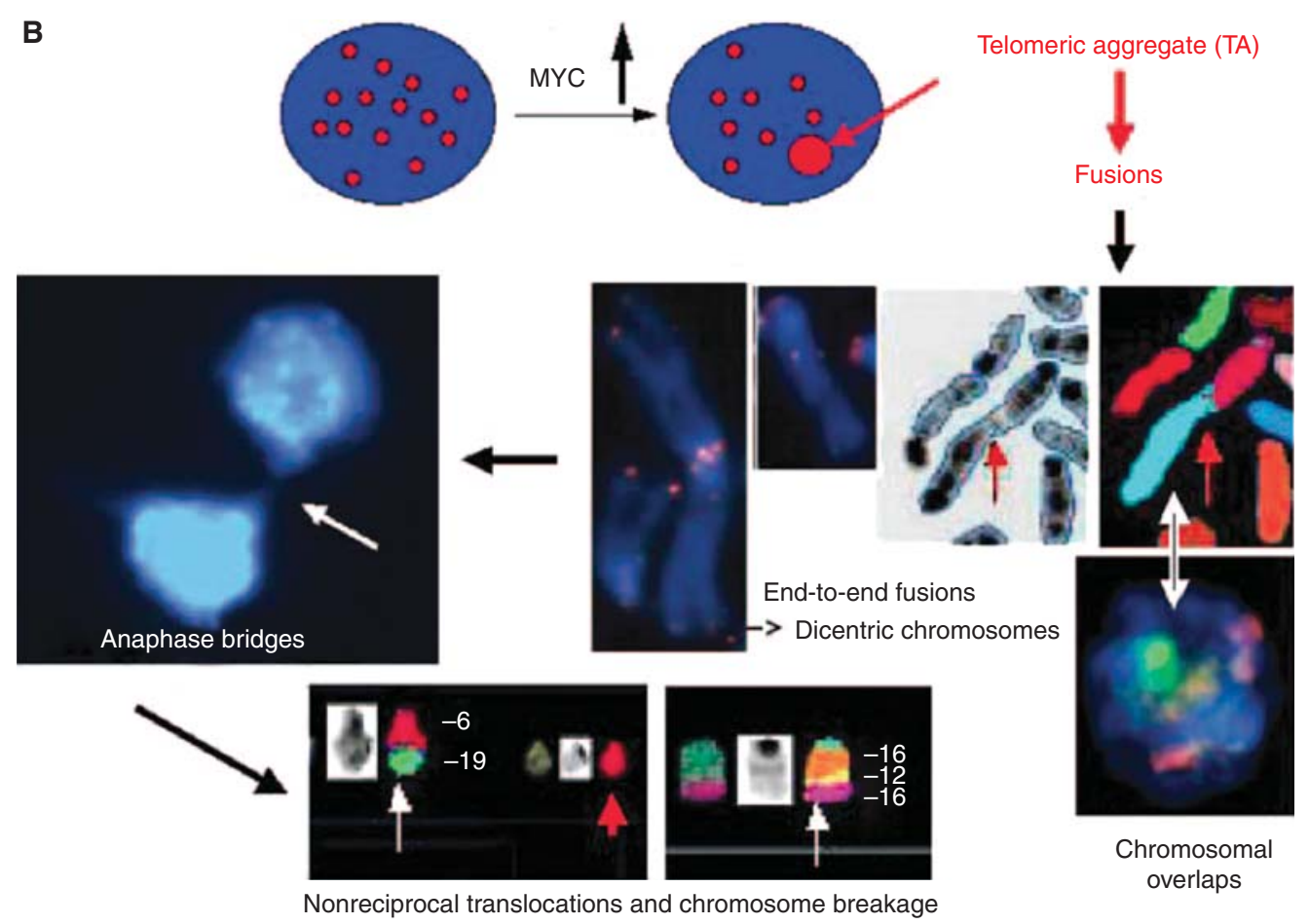

Figure 3. (A) Examples of fused and dicentric chromosomes that form as a result of c-MYC deregulation. (a) Spectral karyotyping (SKY) analysis. c-MYC-dependent formation of dicentric chromosomes (see arrows). Left panel: raw spectral image of a metaphase, middle panel: spectral image of the same metaphase, right panel: inverted DAPI image of the same metaphase, bottom panel: spectral karyotype of the above metaphase. $(b)$ Additional examples of chromosomal fusions as determined by SKY. (B) Overview of c-MYC-dependent remodeling of the interphase nucleus. The figure illustrates the formation of telomeric aggregates that represent, in part, telomeric fusions and move chromosomes into closer vicinity to each other. In anaphase, dicentric chromosomes break generating unbalanced translocations and two telomere-free chromosomal ends. The latter will fuse with new chromosome partners, thus initiating breakage bridge-fusion (BBF) cycles. c-MYC deregulation induces multiple such BBF cycles. (From Mai and Garini 2005; images and legends reproduced with permission.)

positional organization of telomeres and chromosomes, which, in turn, initiate a dynamic process of ongoing genomic instability. The inhibition of MYC at early stages of tumor initiation should be a major goal of cancer therapy (see McKeown and Bradner 2014).

\section{ACKNOWLEDGMENTS}

I am thankful to Michael Mowat, Fred Mushinski, and George Klein for discussions of this article. I thank Monika Fluri who worked with me when our studies on c-MYC and genomic instability began, and Dr. Francis Wiener who introduced me to the mouse model of plasmacytoma and to mouse cytogenetics. I am indebted to many colleagues and friends for collaborations and ongoing discussions.

\section{REFERENCES}

${ }^{*}$ Reference is also in this collection.

Adams JM, Harris AW, Pinkert CA, Corcoran LM, Alexander WS, Cory S, Palmiter RD, Brinster RL. 1985. The c-myc oncogene driven by immunoglobulin enhancers induces lymphoid malignancy in transgenic mice. Nature 318: 533-538.

Arvanitis DA, Spandidos DA. 2008. Deregulation of the $\mathrm{G}_{1}$ / $S$ phase transition in cancer and squamous intraepithelial 
lesions of the uterine cervix: A case control study. Oncol Rep 20: 751-760.

Barlow JH, Faryabi RB, Callén E, Wong N, Malhowski A, Chen HT, Gutierrez-Cruz G, Sun HW, McKinnon P, Wright G, et al. 2013. Identification of early replicating fragile sites that contribute to genome instability. Cell 152: $620-632$.

Beckman RA, Loeb LA. 2005. Genetic instability in cancer Theory and experiment. Semin Cancer Biol 15: 423-435.

Benner SE, Wahl GM, Von Hoff DD. 1991. Double minute chromosomes and homogeneously staining regions in tumors taken directly from patients versus in human tumor cell lines. Anticancer Drugs 2: 11-25.

Bindra RS, Glazer PM. 2007. Co-repression of mismatch repair gene expression by hypoxia in cancer cells: Role of the Myc/Max network. Cancer Lett 252: 93-103.

Bister K, Duesberg PH. 1980. Genetic structure of avian acute leukemia viruses. Cold Spring Harb Symp Quant Biol 44: 801-822.

Bryant HE, Schultz N, Thomas HD, Parker KM, Flower D, Lopez E, Kyle S, Meuth M, Curtin NJ, Helleday T. 2005. Specific killing of BRCA2-deficient tumors with inhibitors of poly(ADP-ribose) polymerase. Nature 434: 913 917.

Bucci B, Agnano ID, Amendola D, Igea D, Citti A, Raza GH, Miceli R, Paula De U, Marchese R, Albini S, et al. 2005. Myc down-regulation sensitizes melanoma cells to radiotherapy by inhibiting MLH1 and MSH2 mismatch repair proteins by inhibiting MLH1 and MSH2 mismatch repair proteins. Clin Cancer Res 11: 2756-2767.

Bunte T, Greiser-Wilke I, Moelling K. 1983. The transforming protein of the MC29-related virus CMII is a nuclear DNA-binding protein whereas $\mathrm{MH} 2$ codes for a cytoplasmic RNA-DNA binding polyprotein. EMBO J 2: $1087-$ 1092.

Campaner S, Amati B. 2012. Two sides of the Myc-induced DNA damage response: From tumor suppression to tumor maintenance. Cell Div 7: 6.

Caporali A, Wark L, Vermolen BJ, Garini Y, Mai S. 2007. Telomeric aggregates and end-to-end chromosomal fusions require myc box II. Oncogene 26: 1398-1406.

Casillas MA, Brotherton SL, Andrews LG, Ruppert JM, Tollefsbol TO. 2003. Induction of endogenous telomerase (hTERT) by c-Myc in WI-38 fibroblasts transformed with specific genetic elements. Gene 316: 57-65.

Chen Q, Shi X, Rudolph C, Yu Y, Zhang D, Zhao X, Mai S, Wang G, Schlegelberger B, Shi Q. 2011. Recurrent trisomy and Robertsonian translocation of chromosome 14 in murine iPS cell lines. Chromosome Res 19: 857-868.

Chernova OB, Chernov MV, Ishizaka Y, Agarwal ML, Stark GR. 1998. MYC abrogates p53-mediated cell cycle arrest in $N$-( phosphonacetyl)-L-aspartate-treated cells, permitting CAD gene amplification. Mol Cell Biol 18: 536-545.

Chiang Y-C, Teng S-C, Su Y-N, Hsieh F-J, Wu K-J. 2003. c-Myc directly regulates the transcription of the NBS1 gene involved in DNA double-strand break repair. J Biol Chem 278: 19286-19291.

Chiswell DJ, Ramsay G, Hayman MJ. 1981. Two virus-specific RNA species are present in cells transformed by defective leukemia virus OK10. J Virol 40: 301-304.
Chuang TC, Moshir S, Garini Y, Chuang AY, Young IT, Vermolen B, van den Doel R, Mougey V, Perrin M, Braun $\mathrm{M}$, et al. 2004. The three-dimensional organization of telomeres in the nucleus of mammalian cells. BMC Biol 2: 12.

Cimprich K, Cortez D. 2008. ATR: An essential regulator of genome integrity. Nat Rev Mol Cell Biol 9: 616-627.

Classon M, Henriksson M, Sümegi J, Klein G, Hammarskiöld ML. 1987. Elevated c-myc expression facilitates the replication of SV40 DNA in human lymphoma cells. Nature 330: 272-274.

Classon M, Henriksson M, Klein G, Sümegi J. 1990. The effect of myc proteins on SV40 replication in human lymphoid cells. Oncogene 5: 1371-1376.

Cole K, Huggins J, Laquaglia M, Hulderman CE, Russell MR, Bosse K, Diskin SJ, Attiyeh EF, Sennett R, Norris $\mathrm{G}$, et al. 2011. RNAi screen of the protein kinome identifies checkpoint kinase 1 (CHK1) as a therapeutic target in neuroblastoma. Proc Natl Acad Sci 108: 3336-3341.

* Conacci-Sorrell M, McFerrin L, Eisenman RN. 2014. An overview of MYC and its interactome. Cold Spring Harb Perspect Med 4: a014357.

Cooper GM. 1982. Transforming genes of chicken bursal lymphomas. J Cell Physiol 1 (Suppl): 209-212.

Dalla-Favera R, Bregni M, Erikson J, Patterson D, Gallo RC, Croce CM. 1982. Human c-myc onc gene is located on the region of chromosome 8 that is translocated in Burkitt lymphoma cells. Proc Natl Acad Sci 79: 7824-7827.

Dang CV. 2012. Links between metabolism and cancer. Genes Dev 26: 877-890.

Dang CV, Li F, Lee LA. 2005. Could MYC induction of mitochondrial biogenesis be linked to ROS production and genomic instability? Cell Cycle 4: 1465-1466.

D'Cruz CM, Gunther EJ, Boxer RB, Hartman JL, Sintasath L, Moody SE, Cox JD, Ha SI, Belka GK, Golant A, et al. 2001. c-MYC induces mammary tumorigenesis by means of a preferred pathway involving spontaneous Kras2 mutations. Nat Med 7: 235-239.

Denis N, Kitzis A, Kruh J, Dautry F, Corcos D. 1991. Stimulation of methotrexate resistance and dihydrofolate reductase gene amplification by c-myc. Oncogene 6: $1453-$ 1457.

Dominguez-Sola D, Ying CY, Grandori C, Ruggiero L, Chen B, Li M, Galloway DA, Gu W, Gautier J, Dalla-Favera R. 2007. Non-transcriptional control of DNA replication by c-Myc. Nature 448: 445-451.

Donehower LA, Harvey M, Slagle BL, McArthur MJ, Montgomery CA Jr, Butel JS, Bradley A. 1992. Mice deficient for p53 are developmentally normal but susceptible to spontaneous tumours. Nature 356: 215-221.

Duesberg PH, Vogt PK. 1979. Avian acute leukemia viruses MC29 and MH2 share specific RNA sequences: Evidence for a second class of transforming genes. Proc Natl Acad Sci 76: 1633-1637.

Eberhardy SR, Farnham PJ. 2001. c-Myc mediates activation of the cad promoter via a post-RNA polymerase II recruitment mechanism. J Biol Chem 276: 48562-48571.

Eilers M, Picard D, Yamamoto KR, Bishop JM. 1989. Chimaeras of myc oncoprotein and steroid receptors cause hormone-dependent transformation of cells. Nature 340: $66-68$. 
El Gedaily A, Bubendorf L, Willi N, Fu W, Richter J, Moch H, Mihatsch MJ, Sauter G, Gasser TC. 2001. Discovery of new DNA amplification loci in prostate cancer by comparative genomic hybridization. Prostate 15: 184-190.

Ellerman V, Bang O. 1908. Experimentelle Leukämie bei Hühnern. Zentralbl Bakteriol Parasitenkd Infectionskr Hyg Abt I 46: 595-609.

Felsher DW, Bishop JM. 1999a. Reversible tumorigenesis by MYC in hematopoietic lineages. Mol Cell 4: 199-207.

Felsher DW, Bishop JM. 1999b. Transient excess of MYC activity can elicit genomic instability and tumorigenesis. Proc Natl Acad Sci 96: 3940-3944.

Fernandez PC, Frank SR, Wang L, Schroeder M, Liu S, Greene J, Cocito A, Amati B. 2003. Genomic targets of the human c-Myc protein. Genes Dev 17: 1115-1129.

Ferrao PT, Bukczynska EP, Johnstone RW, McArthur G. 2011. Efficacy of CHK inhibitors as single agents in MYC-driven lymphoma cells. Oncogene 31: 1-12.

Fest T, Mougey V, Dalstein V, Hagerty M, Milette D, Silva S, Mai S. 2002. c-MYC overexpression in Ba/F3 cells simultaneously elicits genomic instability and apoptosis. Oncogene 21: 2981-2990.

Fest T, Guffei A, Williams G, Silva S, Mai S. 2005. Uncoupling of genomic instability and tumorigenesis in a mouse model of Burkitt's lymphoma expressing a conditional box II-deleted Myc protein. Oncogene 24: 29442953.

Fukasawa K. 2007. Oncogenes and tumour suppressors take on centrosomes. Nat Rev Cancer 7: 911-924.

Fukasawa K, Choi T, Kuriyama R, Rulong S, Vande Woude GF. 1996. Abnormal centrosome amplification in the absence of p53. Science 271: 1744-1747.

Fukasawa K, Wiener F, Vande Woude GF, Mai S. 1997. Genomic instability and apoptosis are frequent in p53 deficient young mice. Oncogene 15: 1295-1302.

* Gabay M, Li Y, Felsher DW. 2014. MYC activation is a hallmark of cancer initiation and maintenance. Cold Spring Harb Perspect Med doi: 10.1101/cshperspect.a014241.

Gadji M, Vallente R, Klewes L, Righolt C, Wark L, Kongruttanachok N, Knecht H, Mai S. 2011. Nuclear remodeling as a mechanism for genomic instability in cancer. $A d v$ Cancer Res 112: 77-126.

Gadji M, Adebayo Awe J, Rodrigues P, Kumar R, Houston DS, Klewes L, Dièye TN, Rego EM, Passetto RF, et al. 2012. Profiling three-dimensional nuclear telomeric architecture of myelodysplastic syndromes and acute myeloid leukemia defines patient subgroups. Clin Cancer Res 18: 3293-3304.

* Gallant P. 2013. MYC function in Drosophila. Cold Spring Harb Perspect Med 3: a014324.

Gandarillas A, Davies D, Blanchard JM. 2000. Normal and c-Myc-promoted human keratinocyte differentiation both occur via a novel cell cycle involving cellular growth and endoreplication. Oncogene 19: 3278-3289.

Gao P, Zhang H, Dinavahi R, Li F, Xiang Y, Raman V, Bhujwalla ZM, Felsher DW, Cheng L, Pevsner J, et al. 2007. HIF-dependent antitumorigenic effect of antioxidants in vivo. Cancer Cell 12: 230-238.

Gaubatz JW. 1990. Extrachromosomal circular DNAs and genomic sequence plasticity in eukaryotic cells. Mutat Res 237: $271-292$.
George RE, Kenyon RM, McGuckin AG, Malcolm AJ, Pearson AD, Lunec J. 1996. Investigation of co-amplification of the candidate genes ornithine decarboxylase, ribonucleotide reductase, syndecan-1 and a DEAD box gene, DDX1, with N-myc in neuroblastoma. United Kingdom Children's Cancer Study Group. Oncogene 12: $1583-$ 1587.

Gonçalves Dos Santos Silva A, Sarkar R, Harizanova J, Guffei A, Mowat M, Garini Y, Mai S. 2008. Centromeres in cell division, evolution, nuclear organization and disease. J Cell Biochem 104: 2040-2058.

Gorrini C, Squatrito M, Luise C, Syed N, Perna D, Wark L, Martinato F, Sardella D, Verrecchia A, Bennett S, et al. 2007. Tip60 is a haplo-insufficient tumour suppressor required for an oncogene-induced DNA damage response. Nature 448: 1063-1067.

Grandori C, Cowlye SM, James LP, Eisenman RN. 2000. The $\mathrm{Myc} / \mathrm{Max} / \mathrm{Mad}$ network and the transcriptional control of cell behavior. Annu Rev Cell Dev Biol 16: 653-699.

Grandori C, Wu K-J, Fernandez P, Ngouenet C, Grim J, Clurman BE, Moser MJ, Oshima J, Russell DW, Swisshelm K, et al. 2003. Werner syndrome protein limits MYC-induced cellular senescence. Genes Dev 17: 15691574.

Graux C, Cools J, Melotte C, Quentmeier H, Ferrando A, Levine R, Vermeesch JR, Stul M, Dutta B, Boeckx N, et al. 2004. Fusion of NUP214 to ABL1 on amplified episomes in T-cell acute lymphoblastic leukemia. Nat Genet 36: 1084-1089.

Guffei A, Lichtensztejn Z, Gonçalves Dos Santos Silva A, Louis SF, Caporali A, Mai S. 2007. c-Myc-dependent formation of Robertsonian translocation chromosomes in mouse cells. Neoplasia 9: 578-588.

Guijon FB, Greulich-Bode K, Paraskevas M, Baker P, Mai S. 2007. Premalignant cervical lesions are characterized by dihydrofolate reductase gene amplification and c-Myc overexpression: Possible biomarkers. J Low Genit Tract Dis 11: 265-272.

Hanahan D, Weinberg RA. 2011. Hallmarks of cancer: The next generation. Cell 144: 646-674.

Hann SR, Abrams HD, Rohrschneider LR, Eisenman RN. 1983. Proteins encoded by $\mathrm{v}-m y c$ and $\mathrm{c}-m y c$ oncogenes: Identification and localization in acute leukemia virus transformants and bursal lymphoma cell lines. Cell 34: 789-798.

Hayward WS, Neel BG, Astrin SM. 1981. Activation of a cellular onc gene by promoter insertion in ALV-induced lymphoid leukosis. Nature 290: 475-480.

Henriksson M, Classon M, Hammarskjöld ML, Klein G, Sumegi J. 1988. The replication activity of SV40 DNA correlates with the level of c-myc expression in human tumor cell lines. Curr Top Microbiol Immunol 141: 202 207.

Hironaka K, Factor VM, Calvisi DF, Conner E, Thorgeirsson SS. 2003. Dysregulation of DNA repair pathways in a transforming growth factor $\alpha / \mathrm{c}$-myc transgenic mouse model of accelerated hepatocarcinogenesis. Lab Invest 83: $643-654$.

Höglund A, Nilsson LM, Muralidharan SV, Hasvold L, Merta P, Rudelius M, Nikolova V, Keller U, Nilsson J. 2011a. Therapeutic implications for the induced levels 
of Chk1 in Myc-expressing cancer cells. Clin Cancer Res 17: 7067-7079.

Höglund A, Stromvall K, Li Y, Forshell LP, Nilsson JA. 2011b. Chk2 deficiency in Myc overexpressing lymphoma cells elicits a synergistic lethal response in combination with PARP inhibition. Cell Cycle 10: 3598-3607.

Hulf T, Bellosta P, Furrer M, Steiger D, Svensson D, Barbour A, Gallant P. 2005. Whole-genome analysis reveals a strong positional bias of conserved dMyc-dependent E-boxes. Mol Cell Biol 25: 3401-3410.

Huppi K, Volfovsky N, Runfola T, Jones TL, Mackiewicz M, Martin SE, Mushinski JF, Stephens R, Caplen NJ. 2008. The identification of microRNAs in a genomically unstable region of human chromosome 8q24. Mol Cancer Res 6: $212-221$.

Huppi K, Pitt J, Wahlberg B, Caplen NJ. 2011. Genomic instability and mouse microRNAs. Toxicol Mech Methods 21: 325-333.

* Hurlin PJ. 2013. Control of vertebrate development by MYC. Cold Spring Harb Perspect Med 3: a014332.

Jain M, Arvanitis C, Chu K, Dewey W, Leonhardt E, Trinh M, Sundberg CD, Bishop JM, Felsher DW. 2002. Sustained loss of a neoplastic phenotype by brief inactivation of MYC. Science 297: 102-104.

Kan NC, Flordellis CS, Garon CF, Duesberg PH, Papas TS. 1983. Avian carcinoma virus MH2 contains a transformation-specific sequence, mht, and shares the myc sequence with MC29, CMII, and OK10 viruses. Proc Natl Acad Sci 80: 6566-6570.

Karlsson A, Deb-Basu D, Cherry A, Turner S, Ford J, Felsher DW. 2003a. Defective double-strand DNA break repair and chromosomal translocations by MYC overexpression. Proc Natl Acad Sci 100: 9974-9979.

Karlsson A, Giuriato S, Tang F, Fung-Weier J, Levan G, Felsher DW. 2003b. Genomically complex lymphomas undergo sustained tumor regression upon MYC inactivation unless they acquire novel chromosomal translocations. Blood 101: 2797-2803.

Khanna KK, Jackson SP. 2001. DNA double-strand breaks: Signaling, repair and the cancer connection. Nat Genet 27: $247-254$.

Koch HB, Zhang R, Verdoodt B, Bailey A, Zhang C-D, Yates JR 3rd, Menssen A, Hermeking H. 2007. Large-scale identification of c-MYC-associated proteins using a combined TAP/MudPIT approach. Cell Cycle 6: 205-217.

Kuschak TI, Taylor C, McMillan-Ward E, Israels S, Henderson DW, Mushinski JF, Wright JA, Mai S. 1999. The ribonucleotide reductase $R 2$ gene is a non-transcribed target of c-Myc-induced genomic instability. Gene 238: 351-365.

Kuschak TI, Kuschak BC, Taylor CL, Wright JA, Wiener F, Mai S. 2002. c-Myc initiates illegitimate replication of the ribonucleotide reductase $R 2$ gene. Oncogene 21: 909-920.

Kuttler F, Mai S. 2007. Formation of non-random extrachromosomal elements during development, differentiation and oncogenesis. Semin Cancer Biol 17: 56-64.

Lacoste S, Wiechec E, Dos Santos Silva AG, Guffei A, Williams G, Lowbeer M, Benedek K, Henriksson M, Klein G, Mai S. 2010. Chromosomal rearrangements after ex vivo
Epstein-Barr virus (EBV) infection of human B cells. Oncogene 29: 503-515.

Land H, Parada LF, Weinberg RA. 1983. Tumorigenic conversion of primary embryo fibroblasts requires at least two cooperating oncogenes. Nature 304: 596-602.

Land H, Chen AC, Morgenstern JP, Parada LF, Weinberg RA. 1986. Behavior of $m y c$ and ras oncogenes in transformation of rat embryo fibroblasts. Mol Cell Biol 6: 19171925.

* Levens D. 2013. Cellular MYCro economics: Balancing MYC function with MYC expression. Cold Spring Harb Perspect Med 3: a014233.

Li Q, Dang CV. 1999. c-Myc overexpression uncouples DNA replication from mitosis. Mol Cell Biol 19: 5339-5351.

Li Z, Vam Calcar S, Qu C, Cavenee WK, Zhang MQ, Ren B. 2003. A global transcriptional regulatory role for $\mathrm{c}-\mathrm{Myc}$ in Burkitt's lymphoma cells. Proc Natl Acad Sci 100: 8164-8169.

Li Z, Owonikoko T, Ramalingam SS, Doetsch PW, Xiao Z, Khuri F, Curran W, Deng X. 2012. c-Myc suppression of DNA double-strand break repair. Neoplasia 14: 11901202.

Lin CY, Lovén J, Rahl PB, Paranal RM, Burge CB, Bradner JE, Lee TI, Young RA. 2012. Transcriptional amplification in tumor cells with elevated c-Myc. Cell 151: 56-67.

Liu Y-C, Li F, Handler J, Huang CRL, Xiang Y, Neretti N, Sedivy JM, Zeller KI, Dang CV. 2008. Global regulation of nucleotide biosynthetic genes by c-Myc. PloS ONE 3: e2722.

Liyanage M, Weaver Z, Barlow C, Coleman A, Pankratz DG, Anderson S, Wynshaw-Boris A, Ried T. 2000. Abnormal rearrangement within the $\alpha / \delta$ T-cell receptor locus in lymphomas from Atm-deficient mice. Blood 96: 19401946.

López-Contreras AJ, Fernandez-Capetillo O. 2010. The ATR barrier to replication-born DNA damage. DNA Repair 9: $1249-1255$.

Louis SF, Vermolen BJ, Garini Y, Young IT, Guffei A, Lichtensztejn Z, Kuttler F, Chuang TC, Moshir S, Mougey V, et al. 2005. c-Myc induces chromosomal rearrangements through telomere and chromosome remodeling in the interphase nucleus. Proc Natl Acad Sci 102: 9613-9618.

Lücke-Huhle C. 1994. Permissivity for methotrexate-induced DHFR gene amplification correlates with the metastatic potential of rat adenocarcinoma cells. Carcinogenesis 15: 695-700.

Lücke-Huhle C, Mai S, Moll J. 1997. C-myc overexpression facilitates radiation-induced DHFR gene amplification. Int J Radiat Biol 71: 167-175.

Luoto KR, Meng AX, Wasylishen AR, Zhao H, Coackley CL, Penn LZ, Bristow RG. 2010. Tumor cell kill by c-MYC depletion: Role of MYC-regulated genes that control DNA double-strand break repair. Cancer Res 70: 8748 8759.

Maclean KH, Kastan MB, Cleveland JL. 2007. Atm deficiency affects both apoptosis and proliferation to aug ment Myc-induced lymphomagenesis. Mol Cancer Res 5: 705-711.

Mai S. 1994. Overexpression of c-myc precedes amplification of the gene encoding dihydrofolate reductase. Gene 148: $253-260$. 
Mai S. 2010. Initiation of telomere-mediated chromosomal rearrangements in cancer. J Cell Biochem 109: 10951102 .

Mai S, Garini Y. 2005. Oncogenic remodeling of the threedimensional organization of the interphase nucleus: c-Myc induces telomeric aggregates whose formation precedes chromosomal rearrangements. Cell Cycle 4: 13271331.

Mai S, Garini Y. 2006. The significance of telomeric aggregates in the interphase nuclei of tumor cells. J Cell Biochem 97: 904-915.

Mai S, Wiener F. 2002. The impact of p53 loss on murine plasmacytoma development. Chromosome Res 10: 239251.

Mai S, Fluri M, Siwarski D, Huppi K. 1996a. Genomic instability in MycER-activated Rat1A-MycER cells. Chromosome Res 4: 365-371.

Mai S, Hanley-Hyde J, Fluri M. 1996b. c-Myc overexpression associated DHFR gene amplification in hamster, rat, mouse and human cell lines. Oncogene 12: 277-288.

Mai S, Hanley-Hyde J, Rainey GJ, Kuschak TI, Paul JT, Littlewood TD, Mischak H, Stevens LM, Henderson DW, Mushinski JF. 1999. Chromosomal and extrachromosomal instability of the cyclin D2 gene is induced by Myc overexpression. Neoplasia 1: 241-252.

Mai S, Guffei A, Fest T, Mushinski JF. 2005. c-Myc deregulation promotes a complex network of genomic instability. In: Hormonal carcinogenesis IV (ed. Li JJ, Li SA, Llombart-Bosch A), pp. 87-97. Springer, New York.

Mannava S, Grachtchouk V, Wheeler LJ, Im M, Zhuang D, Slavina EG, Mathews CK, Shewach DS, Nikiforov MA. 2008. Direct role of nucleotide metabolism in c-Mycdependent proliferation of melanoma cells. Cell Cycle 7: 2392-2400.

Manolov G, Manolova Y. 1972. Marker band in one chromosome 14 from Burkitt's lymphoma. Nature 237: 33-34.

* McKeown MR, Bradner JE. 2014. Therapeutic strategies to inhibit MYC. Cold Spring Harb Perspect Med doi: 10.1101/cshperspect.a014266.

Menssen A, Hermeking H. 2002. Characterization of the c-MYC-regulated transcriptome by SAGE: Identification and analysis of c-MYC target genes. Proc Natl Acad Sci 99: $6274-6279$.

Meyer N, Penn LZ. 2008. Reflecting on 25 years with MYC. Nat Rev Cancer 8: 976-990.

Miltenberger RJ, Sukow KA, Farnham PJ. 1995. An E-boxmediated increase in cad transcription at the $\mathrm{G}_{1} / \mathrm{S}$-phase boundary is suppressed by inhibitory c-Myc mutants. Mol Cell Biol 15: 2527-2535.

Moser R, Toyoshima M, Robinson K, Gurley KE, Howie HL Davison J, Morgan M, Kemp CJ, Grandori C. 2012. MYCdriven tumorigenesis is inhibited by WRN syndrome gene deficiency. Mol Cancer Res 10: 535-545.

Murga M, Campaner S, Lopez-Contreras AJ, Toledo LI, Soria R, Montaña MF, D’Artista L, Schleker T, Guerra C, Garcia E, et al. 2011. Exploiting oncogene-induced replicative stress for the selective killing of Myc-driven tumors. Nat Struct Mol Biol 18: 1331-1335.

Neel BG, Hayward WS, Robinson HL, Fang J, Astrin SM. 1981. Avian leukosis virus-induced tumors have com- mon proviral integration sites and synthesize discrete new RNAs: Oncogenesis by promoter insertion. Cell $\mathbf{2 3}$. 323-334.

Neiman P, Wolf C, Enrietto PJ, Cooper G. 1985. A retroviral myc gene induces preneoplastic transformation of lymphocytes in a bursal transplantation assay. Proc Natl Acad Sci 82: $222-226$

Neiman PE, Kimmel R, Icreverzi A, Elsaesser K, Bowers SJ, Burnside J, Delrow J. 2006. Genomic instability during Myc-induced lymphomagenesis in the bursa of Fabricius. Oncogene 25: 6325-6335.

Neiman PE, Elsaesser K, Loring G, Kimmel R. 2008. Myc oncogene-induced genomic instability: DNA palindromes in bursal lymphomagenesis. PLoS Genet 4: e1000132.

Nesbit CE, Tersak JM, Prochownik EV. 1999. MYC oncogenes and human neoplastic disease. Oncogene 18: $3004-$ 3016.

Nie Z, Hu G, Wei G, Cui K, Yamane A, Resch W, Wang R, Green DR, Tessarollo L, Casellas R, et al. 2012. c-Myc is a universal amplifier of expressed genes in lymphocytes and embryonic stem cells. Cell 151: 68-79.

O'Connell BC, Cheung AF, Simkevich CP, Tam W, Ren X, Mateyak MK, Sedivy JA. 2003. A large scale genomic analysis of c-Myc-regulated gene expression patterns. J Biol Chem 278: 12563-12573.

Ohno S, Babonits M, Wiener F, Spira J, Klein G, Potter M. 1979. Nonrandom chromosome changes involving the Ig gene-carrying chromosomes 12 and 6 in pristane-induced mouse plasmacytomas. Cell 18: 1001-1007.

Orian A, van Steensel B, Delrow J, Bussemaker HJ, Li L, Sawado T, Williams E, Loo LW, Cowley SM, Yost C, et al. 2003. Genomic binding by the Drosophila Myc, Max, Mad/Mnt transcription factor network. Genes Dev 17: 1101-1114.

Palmieri S, Kahn P, Graf T. 1983. Quail embryo fibroblasts transformed by four $\mathrm{v}-m y c$-containing virus isolates show enhanced proliferation but are non tumorigenic. $E M B O J$ 2: 2385-2389.

Payne GS, Bishop JM, Varmus HE. 1982. Multiple arrangements of viral DNA and an activated host oncogene in bursal lymphomas. Nature 295: 209-214.

Pear WS, Ingvarsson S, Steffen D, Münke M, Francke U, Bazin H, Klein G, Sümegi J. 1986. Multiple chromosomal rearrangements in a spontaneously arising $t(6 ; 7)$ rat immunocytoma juxtapose c-myc and immunoglobulin heavy chain sequences. Proc Natl Acad Sci 83: 7376-7380.

Pierce SB, Yost C, Britton JS, Loo LW, Flynn EM, Edgar BA, Eisenman RN. 2004. dMyc is required for larval growth and endoreplication in Drosophila. Development 131: 2317-2327.

Potter M, Wiener F. 1992. Plasmacytomagenesis in mice: Model of neoplastic development dependent upon chromosomal translocations. Carcinogenesis 13: 1681-1697.

Prochownik EV. 2008. c-Myc: Linking transformation and genomic instability. Curr Mol Med 8: 446-458.

Prochownik EV, Li Y. 2007. The ever expanding role for cMyc in promoting genomic instability. Cell Cycle 6: $1024-1029$.

Pusapati RV, Rounbehler RJ, Hong S, Powers JT, Yan M, Kiguchi K, McArthur MJ, Wong PK, Johnson DG. 
2006. ATM promotes apoptosis and suppresses tumorigenesis in response to Myc. Proc Natl Acad Sci 103: 14461451.

Ragimov N, Krauskopf A, Navot N, Rotter V, Oren M, Aloni Y. 1993. Wild-type but not mutant p53 can repress transcription initiation in vitro by interfering with the binding of basal transcription factors to the TATA motif. Oncogene 8: 1183-1193.

* Rahl PB, Young RA. 2014. MYC and transcription elongation. Cold Spring Harb Perspect Med 4: a020990.

Ray S, Atkuri KR, Deb-Basu D, Adler AS, Chang HY, Herzenberg L, Felsher DW. 2006. MYC can induce DNA breaks in vivo and in vitro independent of reactive oxygen species. Cancer Res 66: 6598-6605.

Richards S. 2012. New type of DNA discovered? The Scientist doi: 1-.1126/science.1213307.

Robinson K, Asawachaicharn N, Galloway D, Grandori C. 2009. c-Myc accelerates S-phase and requires WRN to avoid replication stress. PloS ONE 4: e5951.

Rockwood LD, Torrey TA, Kim JS, Coleman AE, Kovalchuk AL, Xiang S, Ried T, Morse HC III, Janz S. 2002. Genomic instability in mouse Burkitt lymphoma is dominated by illegitimate genetic recombinations, not point mutations. Oncogene 21: 7235-7240.

Rounbehler RJ, Li W, Hall MA, Yang C, Fallahi M, Cleveland JL. 2009. Targeting ornithine decarboxylase impairs development of MYCN-amplified neuroblastoma. Cancer Res 69: 547-553.

Rous P. 1910. A transmissible avian neoplasm (sarcoma of the common fowl). J Exp Med 12: 696-705.

Rous P. 1911. A sarcoma of the fowl transmissible by an agent separable from the tumor cells. J Exp Med 13: 397-411.

Schoppy DW, Ragland RL, Gilad O, Shastri N, Peters A, Murga M, Fernandez-Capetillo O, Diehl JA, Brown EJ. 2012. Oncogenic stress sensitizes murine cancers to hypomorphic suppression of ATR. J Clin Invest 122: $241-$ 252.

Scionti I, Michelacci F, Pasello M, Hattinger CM, Alberghini M, Manara MC, Bacci G, Ferrari S, Scotlandi K, Picci P, Serra M. 2008. Clinical impact of the methotrexate resistance-associated genes C-MYC and dihydrofolate reductase (DHFR) in high-grade osteosarcoma. Ann Oncol 19: $1500-1508$.

Shen-Ong GL, Keath EJ, Piccoli SP, Cole MD. 1982. Novel myc oncogene RNA from abortive immunoglobulingene recombination in mouse plasmacytomas. Cell 31: 443-452.

Shibata Y, Kumar P, Layer R, Willcox S, Gagan JR, Griffith JD, Dutta A. 2012. Extrachromosomal microDNAs and chromosomal microdeletions in normal tissues. Science 336: $82-86$.

Shreeram S, Hee WK, Demidov ON, Kek C, Yamaguchi H, Fornace AJ, Anderson CW, Appella E, Bulavin DV. 2006. Regulation of ATM/p53-dependent suppression of mycinduced lymphomas by Wip1 phosphatase. J Exp Med 203: $2793-2799$.

Sidorova JM, Li N, Folch A, Monnat RJ Jr. 2008. The RecQ helicase WRN is required for normal replication fork progression after DNA damage or replication fork arrest. Cell Cycle 7: 796-807.
Silva AG, Graves HA, Guffei A, Ricca TI, Mortara RA, Jasiulionis MG, Mai S. 2010. Telomere-centromere-driven genomic instability contributes to karyotype evolution in a mouse model of melanoma. Neoplasia 12: $11-19$.

Smith G, Taylor-Kashton C, Dushnicky L, Symons S, Wright J, Mai S. 2003. c-Myc-induced extrachromosomal elements carry active chromatin. Neoplasia 5: 110-120.

Solovei I, Kreysing M, Lanctôt C, Kösem S, Peichl L, Cremer T, Guck J, Joffe B. 2009. Nuclear architecture of rod photoreceptor cells adapts to vision in mammalian evolution. Cell 137: 356-368.

Stehelin D, Varmus HE, Bishop JM, Vogt PK. 1976. DNA related to the transforming gene(s) of avian sarcoma viruses is present in normal avian DNA. Nature 260: 170173.

Sun Y, Jiang X, Chen S, Fernandes N, Price BD. 2005. A role for the Tip60 histone acetyltransferase in the acetylation and activation of ATM. Proc Natl Acad Sci 102: 31823187.

Swarnalatha M, Singh AK, Kumar V. 2012. The epigenetic control of E-box and Myc-dependent chromatin modifications regulate the licensing of lamin B2 origin during cell cycle. Nucleic Acids Res 40: 9021-9035.

Tanaka H, Matsumura I, Ezoe S, Satoh Y, Sakamaki T, Albanese C, Machii T, Pestell RG, Kanakura Y. 2002. E2F1 and $\mathrm{c}-\mathrm{Myc}$ potentiate apoptosis through inhibition of NF- $\mathrm{\kappa B}$ activity that facilitates MnSOD-mediated ROS elimination. Mol Cell 9: 1017-1029.

Taub R, Kirsch I, Morton C, Lenoir G, Swan D, Tronick S, Aaronson S, Leder P. 1982. Translocation of the c-myc gene into the immunoglobulin heavy chain locus in human Burkitt lymphoma and murine plasmacytoma cells. Proc Natl Acad Sci 79: 7837-7841.

Taylor C, Mai S. 1998. c-Myc-associated genomic instability of the dihydrofolate reductase locus in vivo. Cancer Detect Prev 22: 350-356.

Thompson CB, Humphries EH, Carlson LM, Chen CL, Neiman PE. 1987. The effect of alterations in myc gene expression on B cell development in the bursa of Fabricius. Cell 51: 371-381.

Vafa O, Wade M, Kern S, Beeche M, Pandita TK, Hampton GM, Wahl GM. 2002. c-Myc can induce DNA damage, increase reactive oxygen species, and mitigate p53 function: A mechanism for oncogene-induced genetic instability. Mol Cell 9: 1031-1044.

Vermolen BJ, Garini Y, Mai S, Mougey V, Fest T, Chuang TC, Chuang AY, Wark L, Young IT. 2005. Characterizing the three-dimensional organization of telomeres. Cytometry A 67: 144-150.

Weaver BA, Silk AD, Montagna C, Verdier-Pinard P, Cleveland DW. 2006. Aneuploidy acts both oncogenically and as a tumor suppressor. Cancer Cell 11: 25-36.

Weinstein IB. 2002. Cancer. Addiction to oncogenes-The Achilles heal of cancer. Science 297: 63-64.

Wiener F, Kuschak TI, Ohno S, Mai S. 1999. Deregulated expression of $\mathrm{c}-\mathrm{Myc}$ in a translocation-negative plasmacytoma on extrachromosomal elements that carry IgH and myc genes. Proc Natl Acad Sci 96: 1396713972. 
MYC and Genomic Instability

Windle B, Draper BW, Yin YX, O'Gorman S, Wahl GM. 1991. A central role for chromosome breakage in gene amplification, deletion formation, and amplicon integration. Genes Dev 5: 160-174.

Wonsey DR, Zeller KI, Dang CV. 2002. The c-Myc target gene PRDX3 is required for mitochondrial homeostasis and neoplastic transformation. PNAS 99: 66496654.
Zasadil LM, Britigan EM, Weaver BA. 2013. 2n or not 2n: Aneuploidy, polyploidy and chromosomal instability in primary and tumor cells. Semin Cell Dev Biol 24: 370379.

Zech L, Haglund U, Nilsson K, Klein G. 1976. Characteristic chromosomal abnormalities in biopsies and lymphoidcell lines from patients with Burkitt and non-Burkitt lymphomas. Int J Cancer 17: 47-56. 


\section{$\&_{\mathrm{CSH}}^{\infty} \&$ Cold Spring Harbor

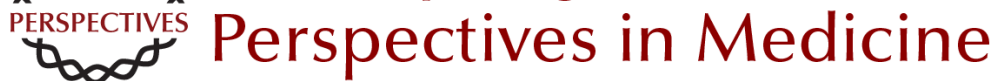

\section{c-MYC-Induced Genomic Instability}

Alexandra Kuzyk and Sabine Mai

Cold Spring Harb Perspect Med 2014; doi: 10.1101/cshperspect.a014373

Subject Collection MYC and the Pathway to Cancer

MYC Cofactors: Molecular Switches Controlling

Diverse Biological Outcomes Stephen R. Hann

MYC Association with Cancer Risk and a New

Model of MYC-Mediated Repression Michael D. Cole

MYC and the Art of MicroRNA Maintenance James N. Psathas and Andrei Thomas-Tikhonenko

MYC Activation Is a Hallmark of Cancer Initiation and Maintenance

Meital Gabay, Yulin Li and Dean W. Felsher

MYC and Mitochondrial Biogenesis

Fionnuala Morrish and David Hockenbery

Synthetic Lethal Screens as a Means to

Understand and Treat MYC-Driven Cancers Silvia Cermelli, In Sock Jang, Brady Bernard, et al.

An Overview of MYC and Its Interactome Maralice Conacci-Sorrell, Lisa McFerrin and Robert N. Eisenman

Socializing with MYC: Cell Competition in Development and as a Model for Premalignant Cancer

Laura A. Johnston
MYC and the Control of Apoptosis Steven B. McMahon

Therapeutic Strategies to Inhibit MYC Michael R. McKeown and James E. Bradner

MYC and the Control of DNA Replication David Dominguez-Sola and Jean Gautier

MYC Regulation of Cell Growth through Control of Transcription by RNA Polymerases I and III Kirsteen J. Campbell and Robert J. White

MYC Degradation Amy S. Farrell and Rosalie C. Sears

MYC and Transcription Elongation Peter B. Rahl and Richard A. Young

c-MYC-Induced Genomic Instability Alexandra Kuzyk and Sabine Mai

Oncogenic Mechanisms in Burkitt Lymphoma Roland Schmitz, Michele Ceribelli, Stefania Pittaluga, et al.

For additional articles in this collection, see http://perspectivesinmedicine.cshlp.org/cgi/collection/ 